\title{
LOGISTICS AND TRANSPORT
}

DOI: https://doi.org/10.30525/978-9934-26-081-0-18

\section{ЩОДО ПИТАНЬ РОСТУ ТА МАРКЕТИНГОВОЇ ЛОГІСТИКИ}

\author{
Тимошенко М. В. \\ кандидат технічних наук, \\ доцент кафедри підприємництва та економіки підприємства \\ Університету митної справи та фінансів \\ м. Дніпро, Україна \\ Попко I. B. \\ студент \\ Університету митної справи та фінансів \\ м. Дніпро, Україна \\ Ссаян А. М. \\ студент \\ Університету митної справи та фінансів \\ м. Дніпро, Україна
}

Економічне зростання здебільшого обумовлено раціональним вбудовуванням національного бізнесу в глобальні ланцюги поставок. Це один 3 найбільш значимих чинників росту - серед таких як забезпечення макроекономічної стабільності, оптимального розміру держави, інклюзивного розвитку та вільного виявлення бізнес ініціативи знизу.

Управління ланцюгами поставок являє підгрунтя оптимізації ринкової діяльності взагалі та здійснюється переважно в рамках концепції маркетингової логістики. У широкому сенсі сутність логістики маркетингу - оптимізація архітектоніки ланцюгів поставок.

Ланцюг поставок відображає усі етапи проходження товарів, починаючи 3 моменту планування їх виробництва до моменту доставки кінцевому покупцю із імплементацією маркетингового міксу 7Р. Саме адекватне управління інтегрованими ланцюгами поставок $\epsilon$ інструментом оптимізації витрат та підвищення рівня конкурентоспроможності бізнесу. 
Дві з найбільш важливих можливостей для логістики маркетингу це удосконалення процесів збору даних по всьому ланцюзі поставок i забезпечення можливості швидкого аналізу великих потоків даних для отримання якісних висновків та підвищення ефективності діяльності. Big data та прогнозована аналітика надають логістичним компаніям додаткову перевагу, необхідну для подолання перешкод. Датчики на вантажних автомобілях, дані про погоду, дані про затори на дорогах, графіки обслуговування автопарку, індикатори стану автопарку в реальному часі та графіки персоналу можуть бути інтегровані в систему, яка аналізує минулі тенденції і надає варіанти рішень.

Діджиталізація - це динамічний інструмент, що перманентно вдосконалюється. На думку віце-президента компанії Gartner Майкла Буркетта майже 75\% лідерів ланцюгів поставок вважають, що цифрові проекти $є$ пріоритетом сучасного бізнесу. Ці технології докорінно змінюють ланцюги поставок i логістичний процес. Визначення власної екосистеми і потреб, оптимізація власного бізнесу є вкрай необхідними.

Основні кроки стосовно діджиталізації бізнес-моделі та бізнесу загалом:

- Інтернет речей (IоT) для вимірювання продуктивності в реальному часі;

- аналітика для прогнозування помилок і автоматизації процесів;

- мобільність для доступу до даних з будь-якого місця;

- API (Application Programming Interface), для обміну даними 3 екосистемою партнерів [1].

Однак і досі більшість компаній покладаються на традиційні процеси, щоб скоротити розрив між попитом і пропозицією. До них відносяться прогнози і плани закупівель, які використовуються для своєчасного замовлення необхідних матеріалів. Щоб врахувати деякі варіації, компанії можуть мати план розподілу, кожен 3 яких зводиться воєдино, щоб дати клієнтові точне вікно доставки. Як наслідок, цей процес $є$ схильним до затримок і прорахунків, які можуть порушити баланс між попитом і пропозицією. 
Проте, діджиталізація бізнес процесу із застосуванням зв'язаних ланцюгів поставок (connected supply chain) iз наскрізною оптимізацією і інтеграцією зовнішніх операцій являє значний ресурс щодо підвищення ефективності компаній.

Стосовно основних компонент зв'язаних ланцюгів поставок набір складається переважно з 6 блоків:

1) планування та виконання;

2) інтегрованість всього ланцюга поставок;

3) прозорість всієї логістичної мережі;

4) закупівельна аналітика з рекомендаціями;

5) взаємозв'язане складування;

6) управління запасними частинами.

Щоб повністю впровадити інтегрований ланцюжок поставок, компанії мають розбудовувати необхідну інфраструктуру, як внутрішню, так і зовнішню, зібрати разом експертів з необхідними навичками і управляти як технологічними, так і організаційними змінами у всій компанії. Це вимагає величезних зусиль у всіх підрозділах однак призводить до значного збільшення прибутку.

Альтернативою щодо створення індивідуального ланцюга поставок $\epsilon$ застосовування готових програмних комплексів, що створюють повністю інтегрований ланцюг поставок із керування запасами і обробкою замовлень в реальному часі. Такі пакети надають повний набір послуг для кращої інтеграції ланцюга поставок Зокрема, підтримуються: підтвердження замовлень, зворотні замовлення, доставка, друк етикеток зі штрих-кодом, друк фірмових пакувальних листів, друк етикеток FEDEX / UPS, коригування матеріальних потоків, автоматичне створення рахунківфактур - і це все в одному програмному забезпеченні.

Згідно з дослідженням IDC (International Data Corporation) світові витрати на технології та послуги, що забезпечують цифрову трансформацію, до 2022 року досягнуть 1,97 трильйона доларів. Величезні обсяги фінансування ілюструють значимість «цифрової революції» в контексті розвитку інструментів поліпшення ефективності ланцюгів поставок [2]. 
Технологічний прорив України в умовах цифрової економіки може бути забезпечено лише за умови інклюзивного розвитку та підвищення ролі науки [3]. Нетоксична щодо наукового середовища інституціональна матриця взагалі являє підгрунтя сталого розвитку соціально-економічної системи. Без, сучасних технологій та інновацій у промисловості ми будемо приречені на роль ресурсної колонії - імпорт товарів з високою доданою вартістю та експорт дефіцитної української сировини.

Особливо має акцентуватися, що якість людського капіталу значним ступенем обумовлюється рівними можливостями щодо доступу до освіти всіх верств населення. Зокрема, знаковою подією в цьому напрямку $є$ Всеукраїнський форум «Україна 30. Освіта i наука» [4], де було анонсовано про створення президентського університету з безкоштовним навчанням на конкурсної основі, що буде базою для підготовки державних топ-менеджерів, які займатимуться цифровою трансформацією країни.

Вкрай необхідно прискорити розробку логістичної стратегії 4.0 в рамках системи стратегічного державного планування та середньострокового бюджетного планування. Зокрема, середньострокове бюджетне планування $є$ дієвим механізмом регулювання економіки [5]. Планування бюджету на 3-5 років вперед дає змогу забезпечити сталий розвиток економіки держави в контексті інновацій нової технологічної революції 4.0 та сформувати важелі впливу на активізацію процесів у сфері ділової активності та споживчого попиту.

Наразі логістика в Україні розвивається у відповідності із світовими тенденціями і здійснює значний вплив на соціальноекономічну систему. Щодо оцінки окремих складових логістичної системи України в контексті показника ефективності логістики (Logistic Performance Index (LPI)), то він здебільшого $є$ кращим, ніж у середньому в регіоні «Свропа та Центральна Азія», але нижчим за відповідний середній показник у світі.

Так згідно останньому рейтингу 2018 р. Україна посідає 66-е місце з 160 країн, знизивши позицію на 5 пунктів у порівнянні 
32014 p. (61-е місце). Але навіть незважаючи на геополітичні виклики - це краща позиція за 102 місце у 2010 році [6].

Україна має нарешті реалізувати свій інноваційний потенціал та поліпшити конкурентоспроможність на базі діджиталізаціі ланцюгів поставок в площині «Логістики маркетингу $4.0 »$.

\section{Література:}

1. Wang J., Ma Y., Zhang L., Gao R.X., Wu D. Deep learning for smart manufacturing: Methods and applications. Journal of Manufacturing Systems. 2018. № 48. P. 144-156.

2. Jeremy Hammant. Connected Supply Chain - Uncovering Opportunities. September 2019. URL: https://www.researchgate.net/publication/348356515_Connected_Supply_Chain_-_Uncovering_Opportunities (дата звернення: 30.05.2021).

3. Тимошенко М.В. Щодо деяких особливостей росту та ролі науки. Інвестииії: практика та досвід. 2020. № 1. С. 44-50.

4. Всеукраїнський форум «Україна 30 . Освіта і наука» 31 травня - 2 червня 2021. URL: https://ukraine30.com/education_science/ (дата звернення: 02.06.2021).

5. Тимошенко М.В. Перспективи запровадження середньострокового бюджетного планування на сучасному етапі розвитку економіки України. Економіка та держава. 2020. № 12. С. 21-26.

6. База даних Світового банку/ Офіційний сайт Світового банку. URL: https://pi.worldbank.org/international/aggregated-ranking (дата звернення: 30.05.2021). 